\begin{tabular}{|c|c|c|}
\hline Beitr. Ent. & Keltern & ISSN 0005-805X \\
\hline $\mathbf{5 6}(2006) 2$ & S. $297-315$ & 15.12 .2006 \\
\hline
\end{tabular}

\title{
On the Turkish species of Sunius. VII. Five new micropte- rous species from western Anatolia and additional records
}

\section{(Coleoptera: Staphylinidae, Paederinae)}

With 62 figures and 2 maps

VOLKer Assing

\section{Summary}

Five micropterous and apparently locally endemic species of Sunius CurTis, 1829 from western Anatolia are described and illustrated: S. bozdagensis sp. n. (Izmir: Boz Dağlar), S. pinniger sp. n. (Izmir), S. fortespinosus sp. n. (Aydın/Izmir: Aydın Dağları), S. sexspinosus sp. n. (Muğla), and S. pinnatus sp. n. (Manisa). Their distributions are mapped. Additional records are presented for two species, among them the first record of S. phasianus (Bordoni) from Iran. 25 Sunius species are now known from Turkey, including one name of doubtful identity. An updated key to the Turkish representatives of the genus is provided.

\section{Keywords}

Coleoptera, Staphylinidae, Paederinae, Sunius, Palaearctic region, Turkey, Iran, taxonomy, new species, new records, distribution, endemism

New species

Sunius bozdagensis sp. n., S. pinniger sp. n., S. fortespinosus sp. n., S. sexspinosus sp. n., S. pinnatus sp. n.

\section{Zusammenfassung}

Fünf ungeflügelte und wahrscheinlich lokalendemische Arten der Gattung Sunius CurTis, 1829 werden aus dem westlichen Anatolien beschrieben und abgebildet $S$. bozdagensis sp. n. (Izmir: Boz Dağlar), S. pinniger sp. n. (Izmir), S. fortespinosus sp. n. (Aydın/Izmir: Aydın Dağları), S. sexspinosus sp. n. (Muğla), and S. pinnatus sp. n. (Manisa). Für alle fünf Arten wird eine Verbreitungskarte erstellt. Für zwei Arten werden weitere Nachweise gemeldet, darunter ein Erstnachweis von S. phasianus (BordonI) für den Iran. 25 SuniusArten sind nunmehr aus der Türkei bekannt, darunter ein bisher nicht deutbarer Name. Eine aktualisierte Bestimmungstabelle der türkischen Sunius-Arten wird erstellt.

\section{Introduction}

Of the 20 species of Sunius CurTis previously recorded from Turkey - including one species of doubtful identity - 14 have reduced hind wings and are local endemics (AssiNG 1995, 2001, 2003, 2005a, 2005b, 2005c). All micropterous species had become known from southern Anatolia. However, in view of the very recent discovery of all these species - none of them was described prior to 2001 - it did not seem unlikely that micropterous Sunius should be present also in other parts of Turkey, but had just not been found. It did 
not come as a complete surprise, therefore, that during a two-week field trip to western Anatolia in spring 2006 five new micropterous species were discovered. Thus, the Sunius fauna of Turkey now comprises 25 species and is far more diverse than that of any other region in the Mediterranean or elsewhere in the Palaearctic region.

\section{Material, methods, and abbreviations}

The material examined is deposited in the following collections:

MNHUB Museum für Naturkunde der Humboldt-Universität, Berlin (J. Frisch)

NHMW Naturhistorisches Museum Wien (H. Schillhammer)

cAnl private collection Sinan Anlaş, Turgutlu

cAss author's private collection

cWun private collection Paul Wunderle, Mönchengladbach

The morphological studies and drawings were carried out using a Stemi SV 11 microscope (Zeiss Germany) and a Jenalab compound microscope (Carl Zeiss Jena) with a drawing tube. For the photographs a digital camera (Nikon Coolpix 995) was used. The maps were generated using the online generic mapping tool (GMT) of the Geomar website at www.aquarius.geomar.de/omc.

Head length was measured from the anterior margin of the clypeus to the posterior carina; elytral length was measured along suture from the apex of the scutellum to the posterior margin.

\section{Species descriptions and additional records}

\section{Sunius dolabrifer Assing}

Additional material examined: Antalya: 4 exs., Geyik Dağları, pass ENE Yarpuz, 15001800 m, 2.IV.2004, leg. Donabauer (NHMW, cAss).

The above specimens represent the westernmost record of this species in Turkey. For a map illustrating the previously known distribution of this species see Assing (2005c).

\section{Sunius phasianus (BORDONI)}

Additional material examined: Iran: 7 exs., Lorestan province, SE Dorud, Saravand (Oshtoran Kuh), 2000 m, 3323N, 49¹0E, 26.VI.2004, leg. Frisch (MNHUB, cAss).

The species is here recorded from Iran for the first time. Its distribution in Turkey was mapped by Assing (2005c).

Sunius bozdagensis sp. n. (Figs 1-11, Map 1)

\section{Type material:}

Holotype ơ: TR [1] - Izmir, $1480 \mathrm{~m}$, Boz Dağlar, above Bozdağ, road to ski resort, 38²1'26N, 2805'39E, 3.IV.2006, V. Assing / Holotypus ơ Sunius bozdagensis sp. n. det. V. Assing 2006 (cAss). Paratypes: $4 \sigma^{\star} \sigma^{\star}, 4$ 우 : same data as holotype (cAss, cWun). 

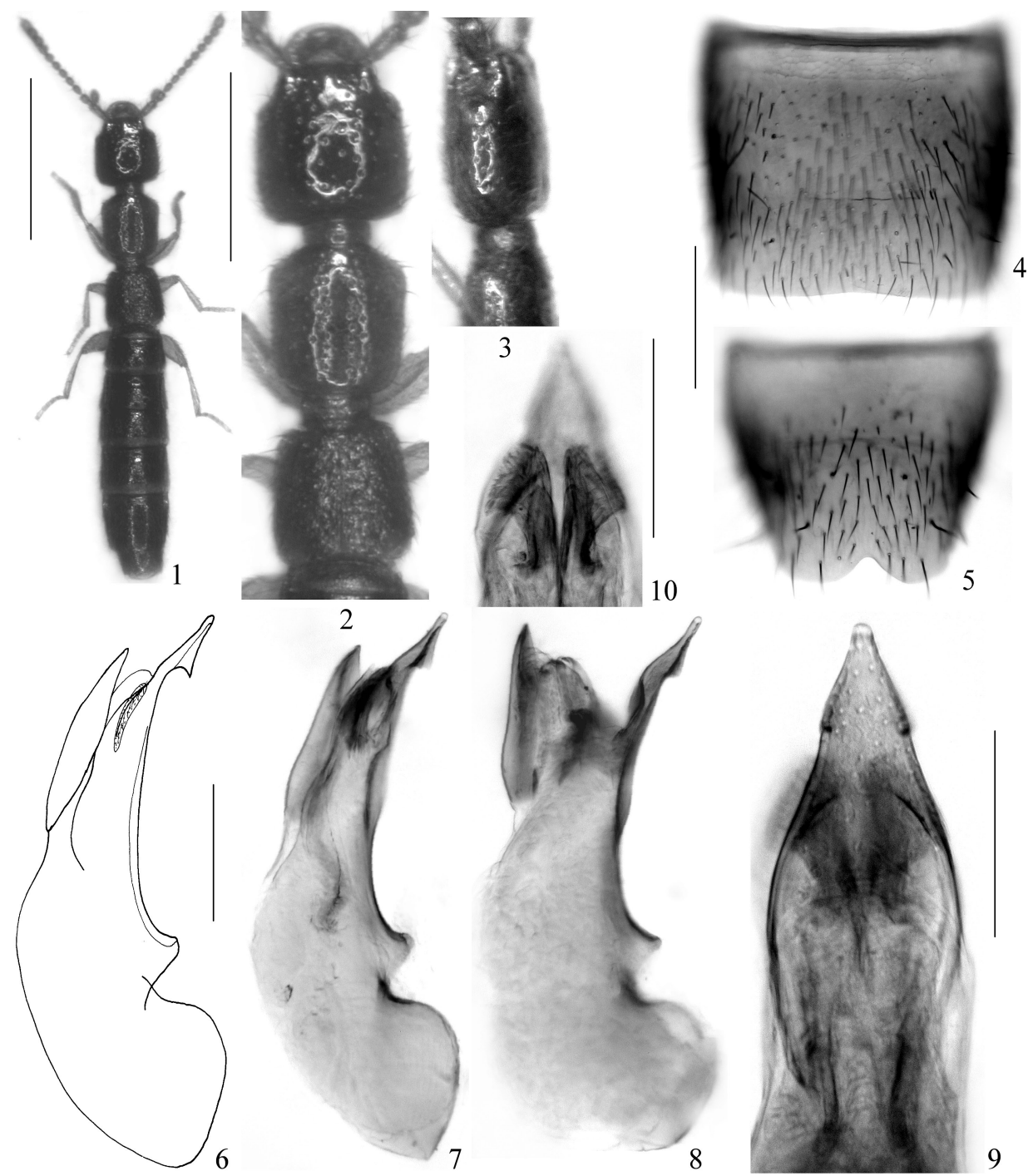

Figs 1-10: Sunius bozdagensis sp. n.: habitus (1); forebody (2); head in lateral view (3); o sternite VII (4); $\sigma^{7}$ sternite VIII (5); aedeagus in lateral view (6-8); ventral process of aedeagus in ventral view (9); apical internal structures of aedeagus in ventral view (10). Scale bars: $1: 1.0 \mathrm{~mm}$; 2-3: $0.5 \mathrm{~mm}$; 4-5: $0.2 \mathrm{~mm}$; 6-10: $0.1 \mathrm{~mm}$.

\section{Description:}

Small species, 2.4-3.1 mm (abdomen extended). Habitus as in Fig. 1. Coloration rather dark (compared to other micropterous species): head dark brown; pronotum bright reddish; elytra brown, darker than pronotum; abdomen blackish; legs pale yellowish; antennae yellowish red.

Head very weakly oblong, less than 1.1 times as long as wide; lateral margins subparallel in dorsal view; puncturation coarse and well-defined, in central dorsal area sparse, in lat- 


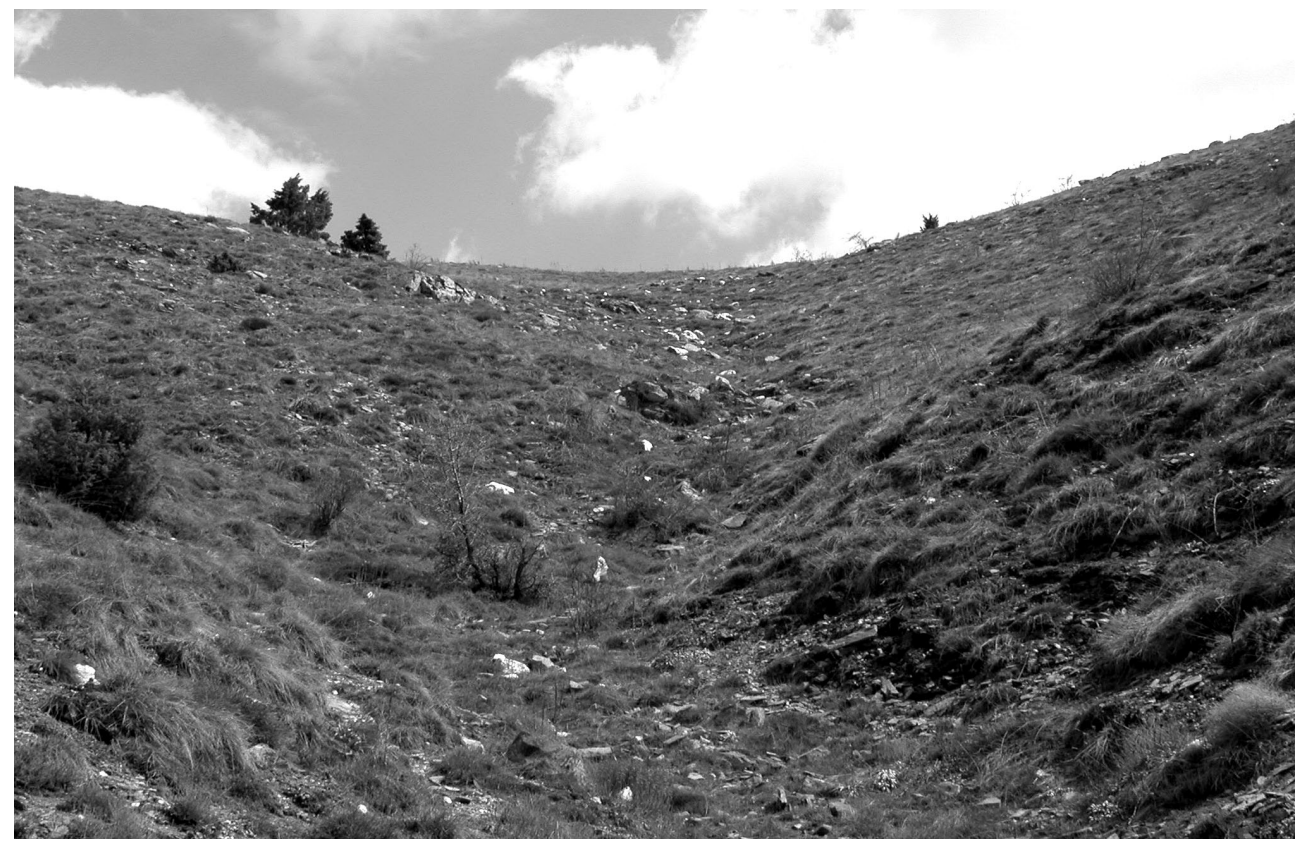

Fig. 11: Type locality of Sunius bozdagensis sp. $\mathrm{n}$.

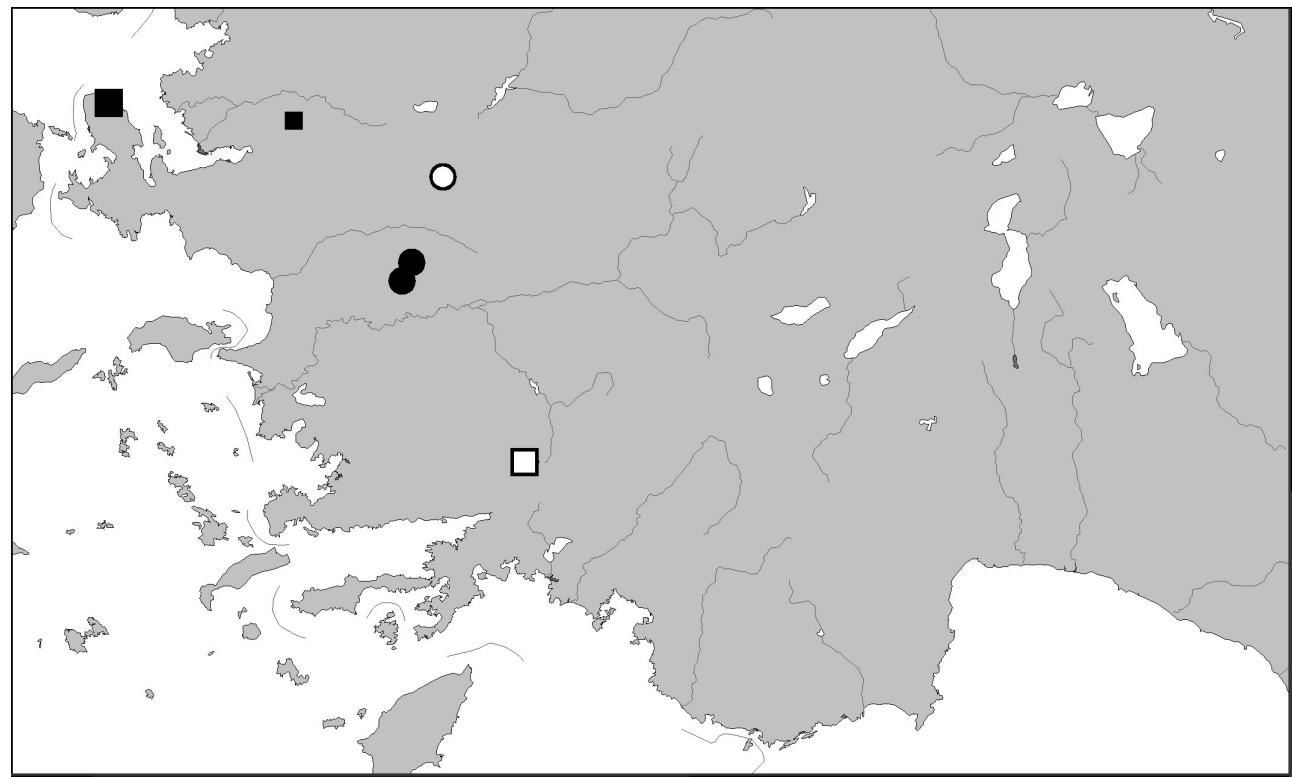

Map 1: Distributions of Sunius bozdagensis (open circle), S. pinniger (large black square), S. fortespinosus (filled circles), S. sexspinosus (open square), and S. pinnatus (small black square) in western Anatolia.

eral areas only slightly denser; microsculpture absent (Fig. 2); eyes small (Fig. 3), weakly projecting from lateral outline of head, postocular region in dorsal view approximately 3 times as long as eyes. 
Pronotum approximately $0.90-0.95$ times as wide as head and 1.1 times as long as wide; microsculpture absent; puncturation as coarse as that of head, but much denser (Fig. 2).

Elytra approximately as wide as and at suture about 0.70 times as long as pronotum; puncturation ill-defined, much finer and shallower than that of pronotum (Fig. 2); microsculpture shallow; surface less shiny than that of pronotum. Hind wings reduced.

Abdomen about 1.15 times as wide as elytra, widest at segments VI-VII; puncturation moderately dense and very fine, barely noticeable; microsculpture shallow, but distinct; posterior margin of tergite VII without palisade fringe.

$\sigma^{\star}$ : sternite VII not distinctly modified (Fig. 4); sternite VIII unmodified, except for the posterior incision (Fig. 5); aedeagus shaped as in Figs 6-10, internal sac without spines and without flagellum.

Etymology: The name (Lat., adj.) is derived from Boz Dağlar, the name of the mountain range where the type locality is situated.

\section{Comparative notes:}

In the keys in Assing (2005b, 2005c), S. bozdagensis would key out at couplet 4 together with $S$. hatayanus Assing, from which the new species is distinguished by the darker and more distinctly bicoloured body and by the shape of the aedeagus, especially the apex of the ventral process and the internal structures. For illustrations of the male sexual characters of S. hatayanus see Figs 16-20 in Assing (2005b).

\section{Distribution and bionomics:}

The type locality is situated in the Boz Dağlar, not far from the ski resort at the highest peak of the range. The type specimens were collected under stones and sifted from grass roots on a grassy north slope at an altitude of almost $1500 \mathrm{~m}$ (Fig. 11).

\section{Sunius pinniger sp. n. (Figs 12-24, Map 1)}

\section{Type material:}

Holotype $0^{\star}$ : TR [4] - Izmir, 440 m, ca. 80 km NW Izmir, W Karaburun, 38³7'39N,

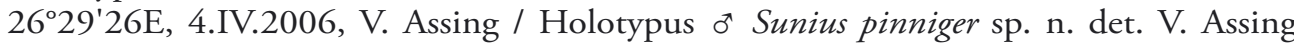
2006 (cAss). Paratypes: 3 ㄲ $o^{\star}, 2$ 우 우: same data as holotype (cAss, cWun); 2 우 우: same data, but leg. S. Anlaş (cAnl).

\section{Description:}

Small species, 2.6-3.3 mm (abdomen extended). Habitus as in Fig. 12. Coloration: forebody uniformly yellowish red; abdomen dark brown to blackish, with the lateral and posterior tergal margins and the apex more or less extensively rufous; legs pale yellowish; antennae yellowish red.

Head weakly oblong, approximately 1.1 times as long as wide; lateral margins subparallel in dorsal view; puncturation coarse, well-defined, and rather dense, in median dorsal area slightly sparser; microsculpture absent (Fig. 13); eyes small (Fig. 14), weakly projecting from lateral outline of head, postocular region in dorsal view approximately 3 times as long as eyes. 


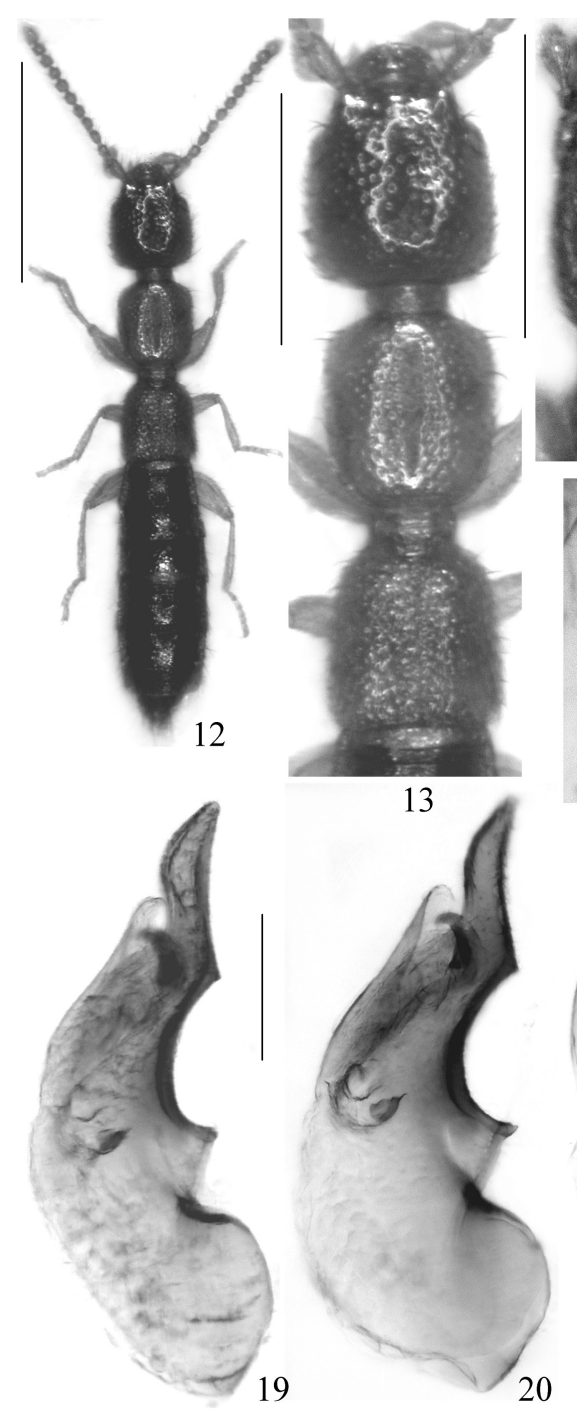

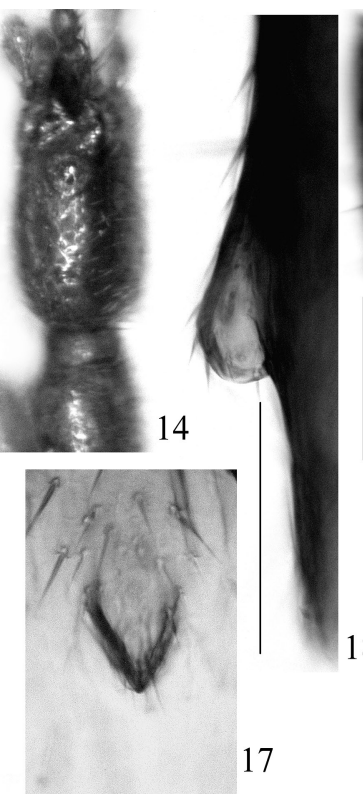

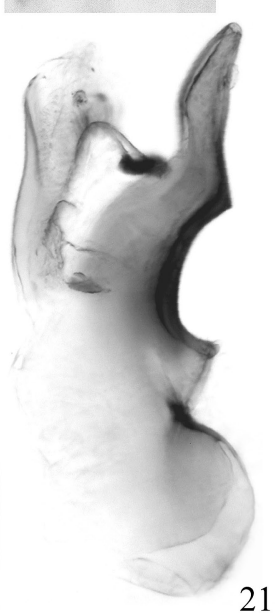

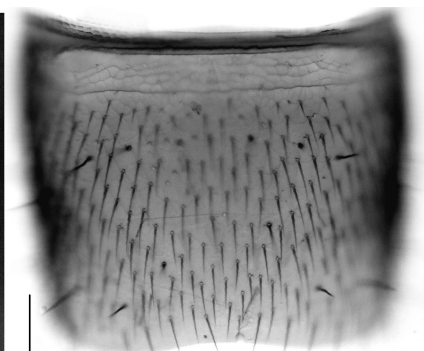

18

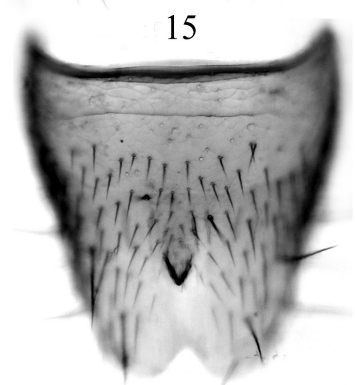

16

Figs 12-23: Sunius pinniger sp. n.: habitus (12); forebody (13); head in lateral view (14); ơ sternite VII (15); $\sigma^{t}$ sternite VIII (16); fin-like process of $o^{t}$ sternite VIII in ventral and in lateral view (17-18); aedeagus in lateral view (19-21); ventral process of aedeagus in ventral view (22); internal structure of aedeagus in ventral view (23). Scale bars: 12: $1.0 \mathrm{~mm}$; 13-14: $0.5 \mathrm{~mm}$; 15-16: $0.2 \mathrm{~mm}$; 17-23: $0.1 \mathrm{~mm}$.

Pronotum approximately 0.90-0.95 times as wide as head and 1.10-1.15 times as long as wide; microsculpture absent; puncturation very dense (except for the impunctate median line) and almost as coarse as that of head (Fig. 13).

Elytra approximately as wide as and at suture about 0.70-0.75 times as long as pronotum; puncturation ill-defined, finer and shallower than that of pronotum; microsculpture shallow (Fig. 13). Hind wings reduced.

Abdomen about 1.15-1.20 times as wide as elytra, widest at segments VI-VII; puncturation moderately dense and fine; microsculpture shallow, but distinct; posterior margin of tergite VII without palisade fringe. 


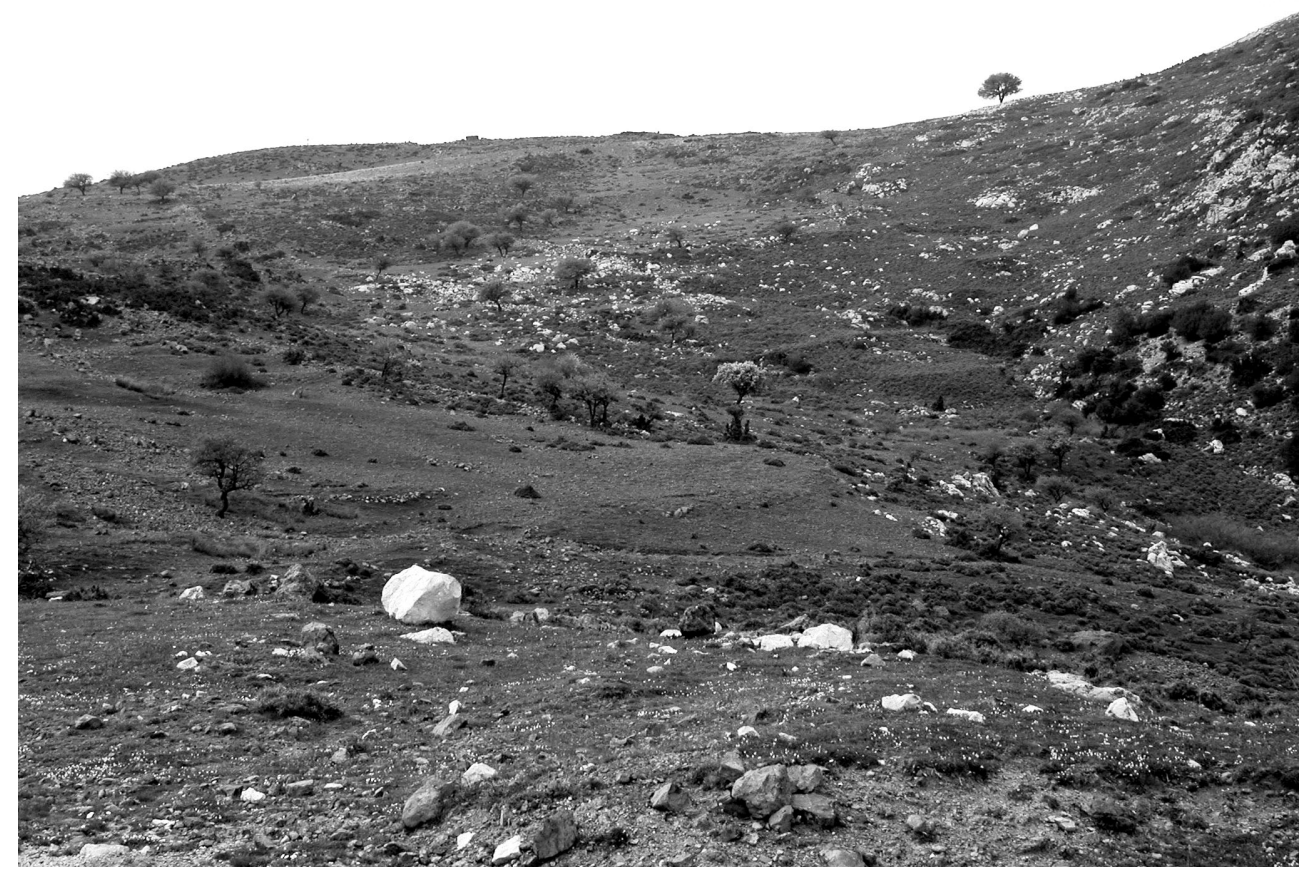

Fig. 24: Type locality of Sunius pinniger sp. n.

$0^{*}$ : sternite VII not distinctly modified (Fig. 15); sternite VIII in the middle with fin-like tubercle or carina (Figs 16-18); aedeagus shaped as in Figs 19-23, internal sac without spines and without flagellum, but with small, weakly sclerotised structure (Fig. 23).

Etymology: The name (Lat., adj.: with fins) alludes to the distinctive shape of the tubercle on the male sternite VIII.

\section{Comparative notes and phylogenetics:}

In the keys in Assing (2005b, 2005c), S. pinniger would key out at couplet 6 together with $S$. aculeatus Assıng, an endemic from the Boncuk Dağ 1 in Muğla. Based on the similarly derived morphology of the aedeagus and the synapomorphic modifications of the male sternite VIII, both species very close relatives. They are reliably distinguished only by the shape of the process of the male sternite VIII (in S. aculeatus longer, more slender in ventral view, and more erect in lateral view) and by the shape of the aedeagus, especially the ventral process, which is more slender in lateral view and broader in ventral view in $S$. aculeatus. For illustrations of the male sexual characters of $S$. aculeatus see Figs 12-19 in Assing (2005a).

\section{Distribution and bionomics:}

The type locality is situated on the peninsula some $80 \mathrm{~km}$ to the northwest of Izmir (Map 1). The specimens were found under stones in a calcareous grassland at an altitude of only $440 \mathrm{~m}$ (Fig. 24). 


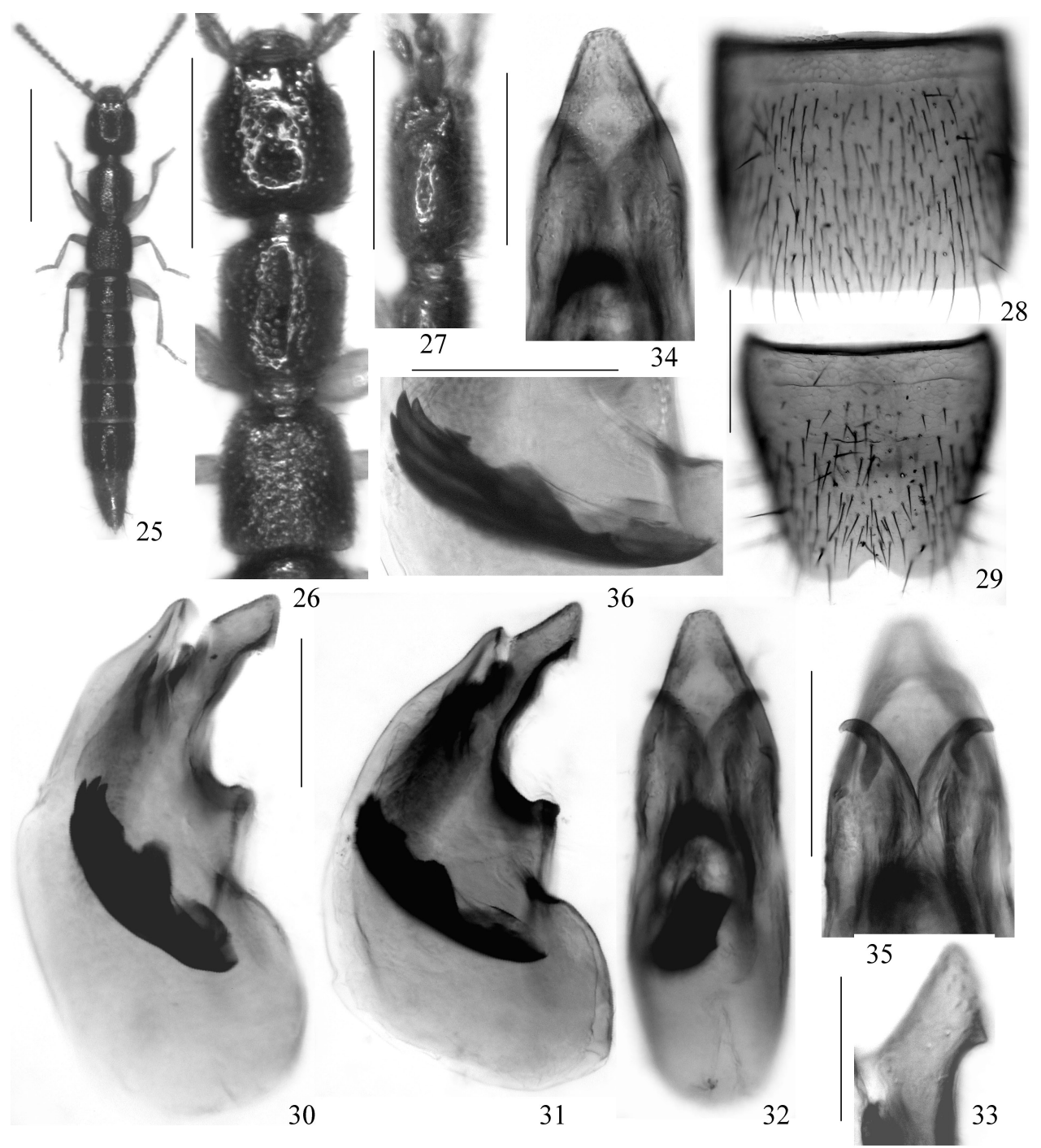

Figs 25-36: Sunius fortespinosus sp. n.: habitus (25); forebody (26); head in lateral view (27); ot sternite VII (28); $\sigma^{\lambda}$ sternite VIII (29); aedeagus in lateral and in ventral view (30-32); apex of ventral process of aedeagus in lateral view (33); ventral process of aedeagus in ventral view (34); apical internal structure of aedeagus in ventral view (35); spines in internal sac of aedeagus in lateral view (36). Scale bars: $25: 1.0 \mathrm{~mm}$; 26-27: $0.5 \mathrm{~mm}$; 28-29: $0.2 \mathrm{~mm}$; 30-32, 34-36: $0.1 \mathrm{~mm}$; 33: $0.05 \mathrm{~mm}$.

Sunius fortespinosus sp. n. (Figs 25-37, Map 1)

\section{Type material:}

Holotype ơ: TR [5] - Aydın, 15 km NNE Aydın, Imambaba T., 1410 m, 3756'38N, $27^{\circ} 53^{\prime}$ 40E, 5.IV.2006, V. Assing / Holotypus ơ Sunius fortespinosus sp. n. det. V. Assing 2006 (cAss). Paratypes: $4 \sigma^{\star} \sigma^{*}, 2$ ㅇ ㅇ: same data as holotype (cAss, cWun); $1 \sigma^{*}$ : same data, but leg. Wunderle (cWun); $1 \sigma^{*}, 1$ ㅇ: TR [18] - Izmir, WSW Hamamköy, Murtat

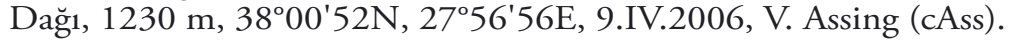




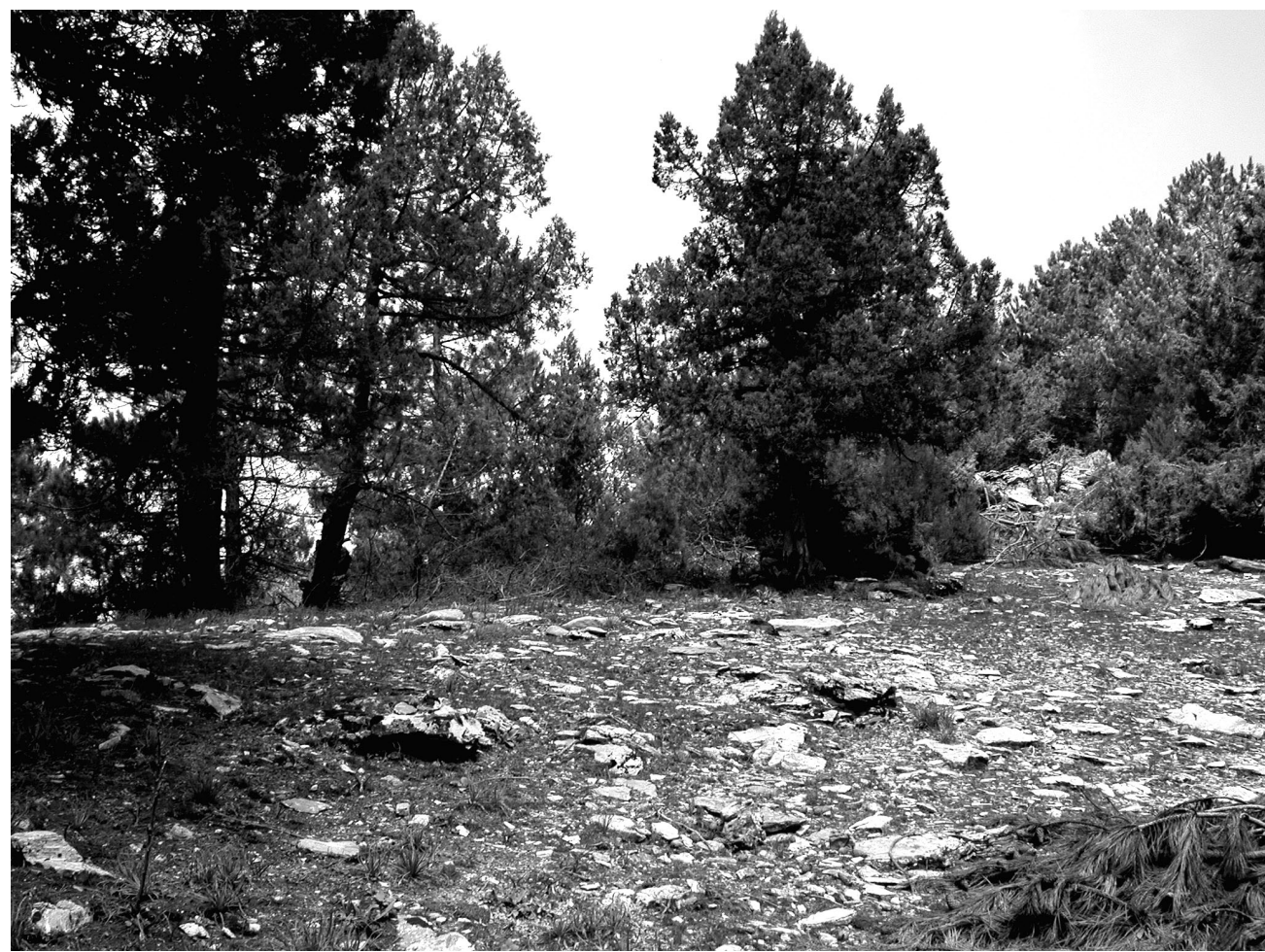

Fig. 37: Locality where the holotype and most of the paratypes of Sunius fortespinosus sp. n. were found.

\section{Description:}

Small species, 2.7-3.3 mm (abdomen extended). Habitus as in Fig. 25. Coloration: forebody uniformly yellowish red to reddish brown, with the elytra sometimes darker; abdomen dark brown to blackish, with the paratergites mostly paler brown; legs pale yellowish; antennae yellowish red.

Head very weakly oblong, less than 1.1 times as long as wide; lateral margins subparallel or indistinctly diverging posteriad in dorsal view; puncturation coarse, well-defined, and relatively sparse, in lateral area slightly denser than in median dorsal area; microsculpture absent (Fig. 26); eyes small (Fig. 27), weakly projecting from lateral outline of head, postocular region in dorsal view approximately 3 times as long as eyes or nearly so.

Pronotum approximately 0.90-0.95 times as wide as head and about 1.10 times as long as wide; microsculpture absent; puncturation very dense (except for the impunctate median line) and about as coarse as that of head (Fig. 26).

Elytra approximately as wide and at suture about 0.75 times as long as pronotum; puncturation ill-defined, much finer and shallower than that of pronotum; microsculpture shallow (Fig. 26). Hind wings reduced.

Abdomen about 1.15 times as wide as elytra, widest at segments VI-VII; puncturation relatively dense and fine; microsculpture shallow; posterior margin of tergite VII without palisade fringe. 
$0^{\star}$ : sternite VII not distinctly modified (Fig. 28); sternite VIII unmodified, except for posterior incision (Fig. 29); aedeagus shaped as in Figs 30-36, internal sac with series of five stout, long, and distinctly sclerotised spines (Fig. 36).

Etymology: The name (Lat., adj.) refers to the series of long and stout spines in the internal sac of the aedeagus.

\section{Comparative notes:}

In the keys in Assing (2005b, 2005c), S. fortespinosus would key out at couplets 3-3b together with S. longispinosus Assing, S. brevispinosus Assing, S. pauli Assing, and $S$. amanensis Assing. From all these species, S. fortespinosus is readily separated by the completely different shape of the ventral process of the aedeagus and by the longer and darker spines in the internal sac. For illustrations of the male sexual characters of these species see the figures in Assing (2005b, 2005c).

\section{Distribution and bionomics:}

The two localities are situated in the western parts of the Aydın Dağları (Map 1), where the species is probably endemic. The specimens were found under stones and in gravel on a small patch of grassland at the edge of a pine forest (Fig. 37) and on a rocky north slope with scattered oak trees and scanty vegetation at altitudes of 1230 and $1410 \mathrm{~m}$.

\section{Sunius sexspinosus sp. n. (Figs 38-48, Map 1)}

\section{Type material:}

Holotype ơ: TR [20] - Muğla, $15 \mathrm{~km}$ ENE Muğla, $1190 \mathrm{~m}$, pasture with stones, $37^{\circ} 14^{\prime} 58 \mathrm{~N}, 28^{\circ} 30^{\prime} 07 \mathrm{E}, 10 . \mathrm{IV} .2006$, V. Assing / Holotypus ơ Sunius sexspinosus sp. n. det. V. Assing 2006 (cAss). Paratypes: $3 \sigma^{*} \sigma^{*}, 6$ ㅇ 우 : same data as holotype (cAss); $2 \sigma^{*} \sigma^{*}$, 2 우 오 : same data, but leg. Wunderle (cWun).

\section{Description:}

Small species, 2.6-3.2 mm (abdomen extended). Habitus as in Fig. 38. In external morphology highly similar to $S$. fortespinosus, but distinguished as follows:

Coloration on average paler: forebody yellowish, elytra of same colour as head and pronotum; paratergites and apex of abdomen reddish to reddish brown. Puncturation of head on average slightly sparser, especially in median dorsal area. Elytra on average slightly shorter and more slender, approximately 0.70 times as long as pronotum (Fig. 39).

$\sigma^{\top}$ : sternite VII not distinctly modified (Fig. 40); sternite VIII unmodified, except for posterior incision (Fig. 41); aedeagus shaped as in Figs 42-47, internal sac with series of six stout, long, and distinctly sclerotised spines (Fig. 47).

Etymology: The name (Lat., adj.) refers to the presence of six stout spines in the internal sac of the aedeagus.

\section{Comparative notes:}

Based on the male sexual characters, especially the morphology of the aedeagus (shape of apex of ventral process, shape of spines in internal sac), S. sexspinosus is the adelphotaxon of S. fortespinosus. Both species are reliably distinguished only by the male primary 


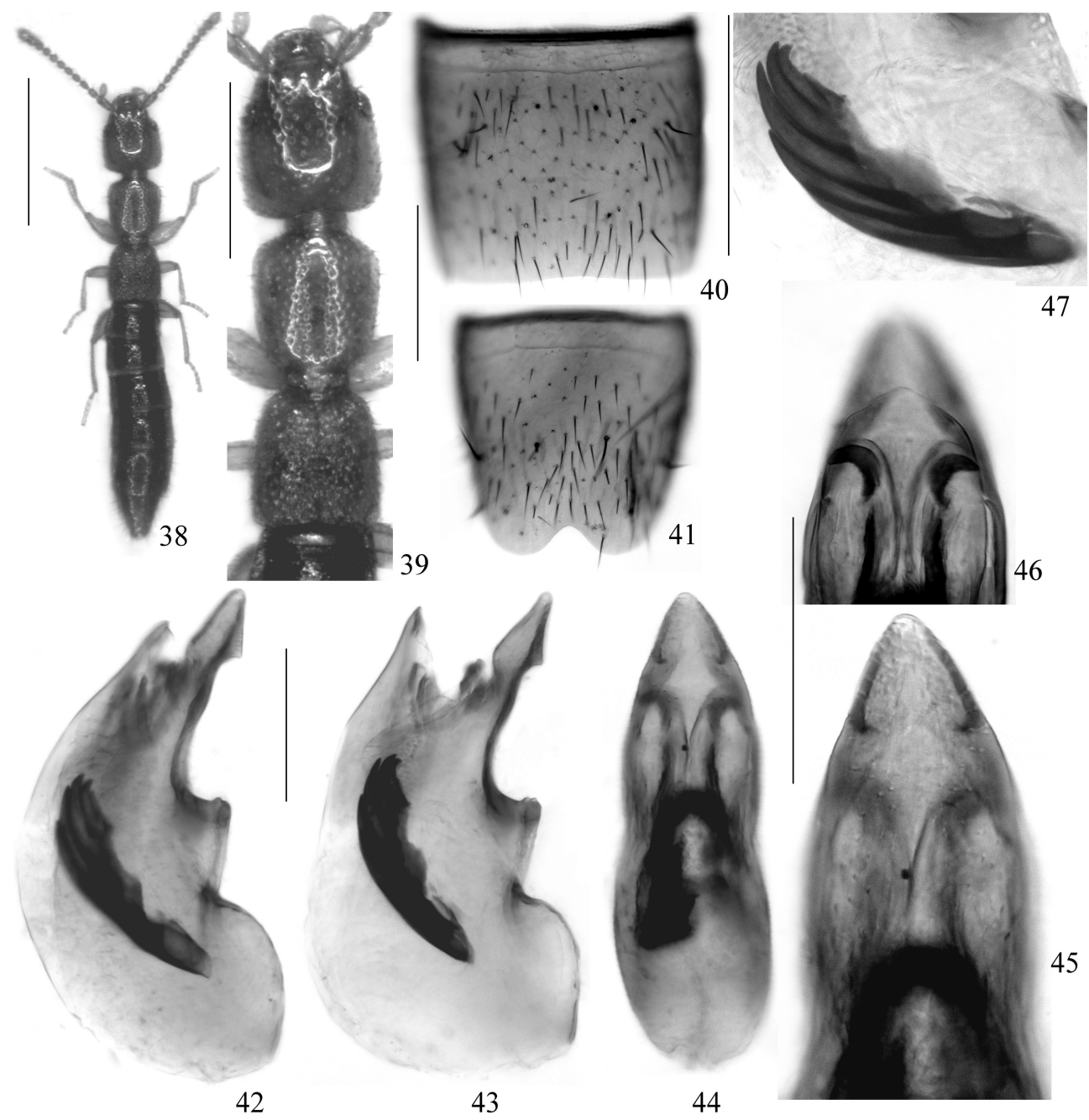

Figs 38-47: Sunius sexspinosus sp. n.: habitus (38); forebody (39); $0^{\uparrow}$ sternite VII (40); ơ sternite VIII (41); aedeagus in lateral and in ventral view (42-44); ventral process of aedeagus in ventral view (45); apical internal structure of aedeagus in ventral view (46); spines in internal sac of aedeagus in lateral view (47). Scale bars: 38: $1.0 \mathrm{~mm}$; 39: $0.5 \mathrm{~mm}$; 40-41: $0.2 \mathrm{~mm}$; $42-47: 0.1 \mathrm{~mm}$.

sexual characters, particularly the shape of the apex of the ventral process (see Figs 30$34,42-45$ ), as well as the number and colour of the spines in the internal sac (darker in S. fortespinosus than in $S$. sexspinosus).

\section{Distribution and bionomics:}

The type locality is situated some $15 \mathrm{~km}$ to the northeast of Muğla (Map 1). The type specimens were found under stones and sifted from grass roots between limestone gravel on a pasture with shrubs, very close to a field, at an altitude of about $1200 \mathrm{~m}$ (Fig. 48). 


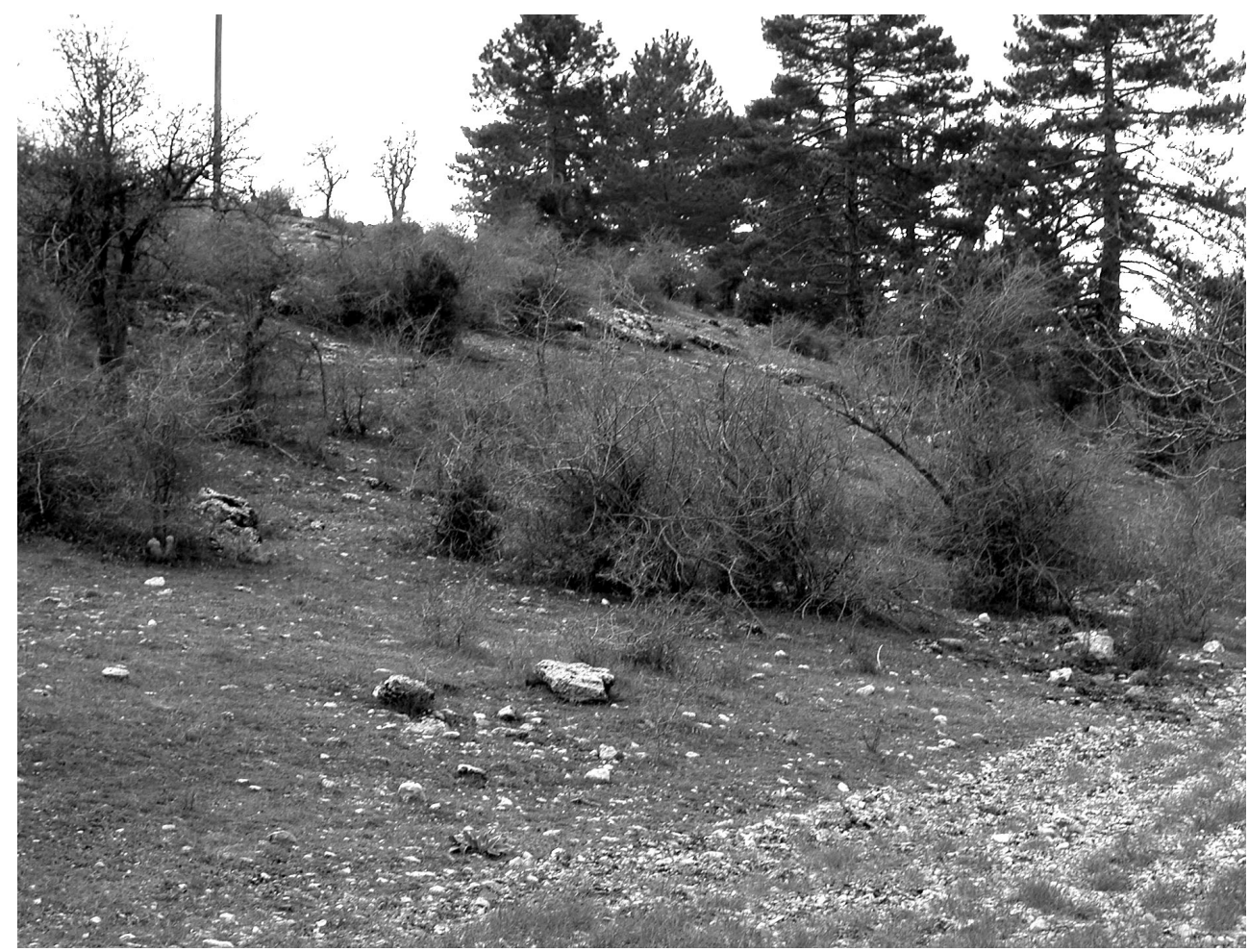

Fig. 48: Type locality of Sunius sexspinosus sp. n.

Sunius pinnatus sp. n. (Figs 49-62, Map 1)

\section{Type material:}

Holotype ơ: TR [30] - Manisa, $10 \mathrm{~km}$ S Manisa, Karadağ, $1200 \mathrm{~m}$, roadside, 38³3'26N, $27^{\circ} 23^{\prime} 13 \mathrm{E}, 15 . \mathrm{IV} .2006$, P. Wunderle / Holotypus ơ Sunius pinnatus sp. n. det. V. Assing 2006 (cAss). Paratypes: 2 우 : same data as holotype (cWun); 1 온 same data, but leg. Assing (cAss).

\section{Description:}

Small species, 2.7-3.3 mm (abdomen extended). Habitus as in Fig. 49. In external morphology extremely similar to $S$. pinniger and similar species (Figs 50-51). Distinguished only by the male sexual characters:

$0^{*}$ : sternite VII not distinctly modified (Fig. 52); sternite VIII with tubercle of distinctive shape (Figs 53-56); aedeagus shaped as in Figs 57-59, internal sac without spines, with minute subapical and pair of slender apical internal structures (Figs 60-61).

Etymology: The name (Lat., adj.: with wings) refers to the shape of the tubercle on the male sternite VIII.

\section{Comparative notes:}

Based on the male sexual characters, this species is most closely related to $S$. aculeatus from the Boncuk Dağı in Muğla and to $S$. pinniger from the Ak Dağ on the peninsula to 


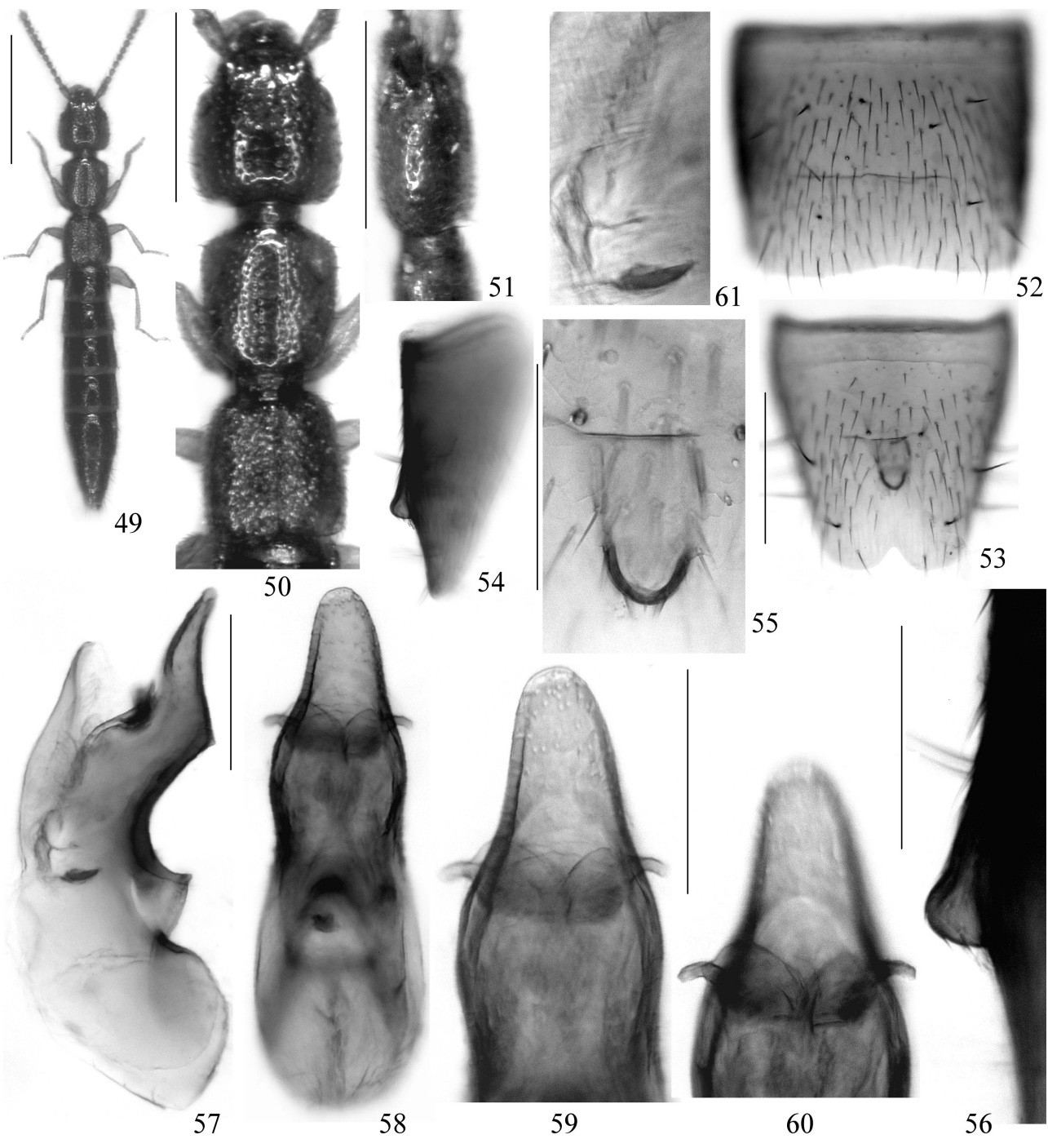

Figs 49-61: Sunius pinnatus sp. n.: habitus (49); forebody (50); head in lateral view (51), ơ sternite VII (52); $\sigma^{7}$ sternite VIII in ventral and in lateral view (53-54); tubercle of $o^{\text {t }}$ sternite VIII in ventral and in lateral view (55-56); aedeagus in lateral and in ventral view (57-58); ventral process of aedeagus in ventral view (59); apical internal structure of aedeagus in ventral view (60); subapical internal structure of aedeagus (61). Scale bars: 49: $1.0 \mathrm{~mm}$; 50-51: $0.5 \mathrm{~mm}$; 52-54: $0.2 \mathrm{~mm}$; 55-61: $0.1 \mathrm{~mm}$.

the northwest of Izmir. It is separated from both species reliably only by the shape of the aedeagus and of the tubercle on the male sternite VIII.

\section{Distribution and bionomics:}

Sunius pinnatus was discovered in the Karadağ range (Spil [=Sipil] nature reserve) to the south of Manisa, where it is probably endemic, as is suggested by the restricted distributions of other micropterous Sunius species occurring in Turkey and by the adaptive reductions of eye size, elytra, hind wings, and pigmentation. The type specimens were 


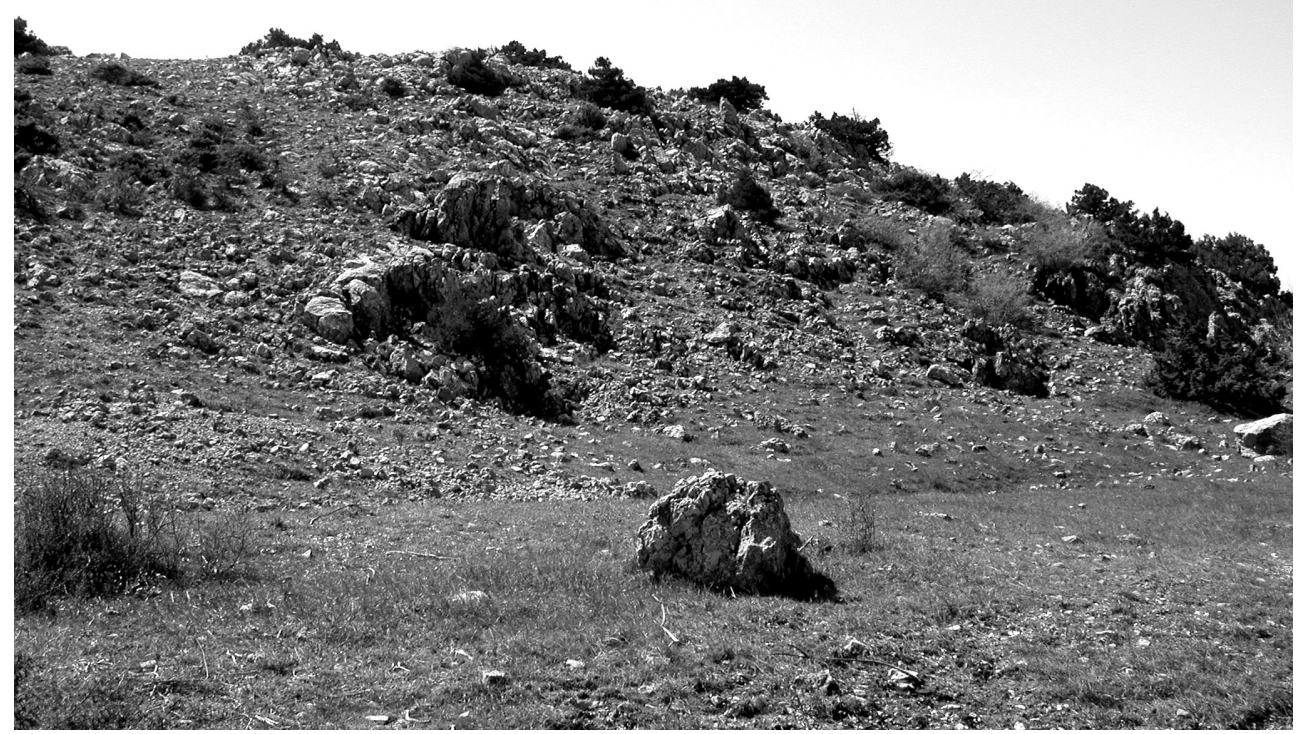

Fig. 62: Type locality of Sunius sexspinosus sp. n.

found under stones on a patch of calcareous grassland very close to the roadside at an altitude of $1200 \mathrm{~m}$, together with an undescribed species of Geostiba THомson (Fig. 62).

\section{Distribution of micropterous Sunius species in Turkey}

As far as is currently known, all 19 micropterous Sunius of Turkey are local endemics; all of them are known only from their respective type localities and their immediate vicinity. Up until now they have become known only from southern and western Anatolia (Map 2), but the possibility that micropterous representatives may be present also in northern Anatolia cannot be ruled out; in southern and western Anatolia they had been overlooked until only a few years ago. Moreover, there is still a considerable stretch of land in southern Anatolia, from western Antalya to western Mersin, from where no micropterous Sunius have yet been recorded, a gap to be closed by future studies. From some areas only females have become available (Map 2), which may or may not refer to any of the described species; for a reliable identification of micropterous Sunius, males are essential.

\section{Updated key to the Turkish species of Sunius}

The following key includes all the species known from Turkish territory, except for $S$. adanensis (LOKAY), whose original description is based only on females from the surroundings of Adana and from Syria and whose identity still remains doubtful. Species identification mainly relies on the male primary and secondary characters; an iden- 


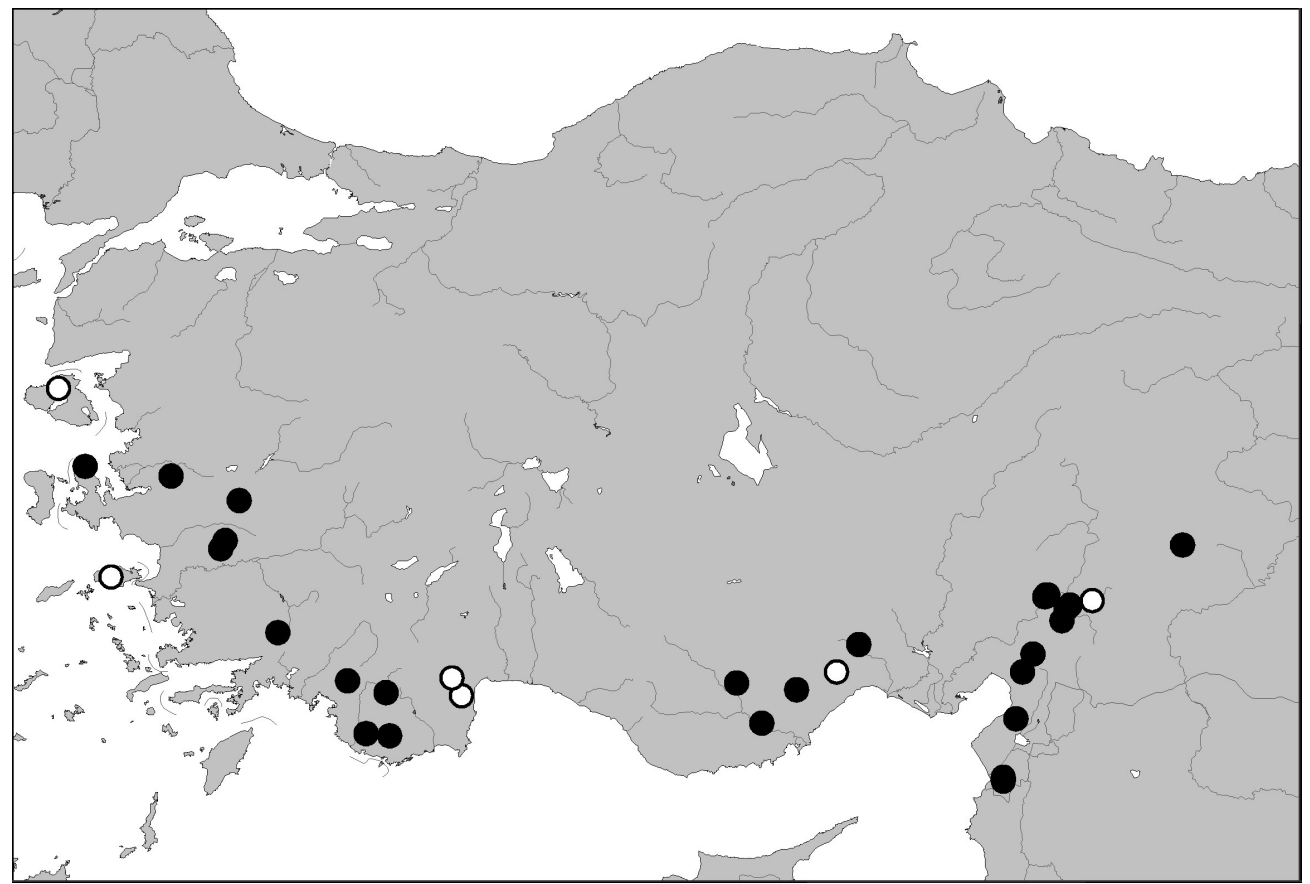

Map 2: Distribution of micropterous Sunius in Turkey (including some Greek islands); open circles: records based only on females, identity of species unknown. Almost every dot (black circles) represents a distinct species.

tification of females is generally difficult or impossible. The references to figures and maps in previously published articles are abbreviated as follows: A95 = Assing (1995); A01 = Assing (2001); A03 = Assing (2003); A05a = Assing (2005a); A05b = Assing (2005b); A05c = Assing (2005c); A05d = Assing (2005d).

1. Smaller species, size (normal preparation) usually $<3.4 \mathrm{~mm}$. Head noticeably wider than pronotum. Eyes less than half - usually about one third - the length of postgenae in dorsal view. Forebody uniformly ferrugineous or testaceous. Abdominal tergite VII without palisade fringe at posterior margin. $\sigma^{\star}$ : sternite VII not or only weakly modified; sternite VIII in posterior median area with densely pubescent tubercle, with conspicuous process, or without such modifications. Aedeagus often with spines, but without rod in internal sac. Southern and western Anatolia.

- $\quad$ Larger species, body size in normal preparation $>3.0 \mathrm{~mm}$. Head relatively smaller, approximately as wide as or narrower than pronotum. Eyes at least half the length of postgenae in dorsal view, in most species much larger. Forebody in most species bicoloured, with the head darker than the pronotum. Abdominal tergite VII with or without palisade fringe. $\sigma^{\top}$ : sternite VII more or less depressed posteriorly, often with darker, stouter, and diagonal pubescence in posterior median area; sternite VIII without tubercle or process. Aedeagus with long rod-like structure in internal sac. 18

2. $\sigma^{\lambda}$ : sternite VIII without conspicuous modifications. 3

$\sigma^{*}$ : sternite VIII either with distinct spine, tubercle, and/or with patch of tomentose or dense pubescence near posterior emargination. 
3. $\sigma^{*}$ : aedeagus with series of distinctly sclerotised spines in internal sac. ......................... 4

$\sigma^{\star}$ : aedeagus without series of distinctly sclerotised spines in internal sac. ..................... 9

4. $0^{*}$ : ventral process of aedeagus apically long and slender in lateral view; spines in internal sac of aedeagus shorter and/or apically distinctly curved. Central southern Anatolia. ... 5 $\sigma^{*}$ : ventral process of aedeagus apically distinctly shorter and stouter (Figs 30-31, 42-43); spines in internal sac of aedeagus conspicuously long and apically at most weakly curved. Western Anatolia. ... 8

5. $\sigma^{*}$ : ventral process of aedeagus in lateral view apically distinctly bent; internal sac of aedeagus with row of 3-4 spines of subequal length (plus smaller spines) (Figs A05b: 10-12). Antakya: Southern Nur Dağları (Map A05b: 3). S. amanensis Assing $\sigma^{*}$ : ventral process of aedeagus in lateral view weakly curved at most; internal sac of aedeagus with one or two very large spines and additional distinctly smaller spines. Distribution different. 6

6. $\sigma^{*}$ : apex of ventral process of aedeagus in lateral view less slender; large spine in internal sac of aedeagus strongly curved (Figs A05c: 15-18). S-Malatya: Malatya Dağları (Map A05c: 2). S. pauli Assing $\sigma^{*}$ : apex of ventral process of aedeagus in lateral view more slender; large spine in internal sac of aedeagus moderately curved at most. Species from Kahramanmaraş. 7

7. $0^{*}$ : sclerotised spines in internal sac shorter (Figs A05c: 3-7). Area to the west of Kahramanmaraş: Başkonuş Yaylası (Map A05c: 2).

S. brevispinosus Assing $\sigma^{*}$ : sclerotised spines in internal sac longer (Figs A05c: 9-11). Area to the southwest of Kahramanmaraş (Map A05c: 2). S. longispinosus Assing

8. Coloration of forebody usually yellowish brown to reddish brown, with the elytra sometimes darker than head and pronotum. $\sigma^{-1}$ : ventral process of aedeagus shorter, in lateral view somewhat bent, and apically of distinctive shape (Figs 30-31, 33), in ventral view apically rounded (Figs 32, 34); internal sac of aedeagus with 5 darker and longer spines (Fig. 36). Izmir/Aydın: Aydın Dağları (Map 1). S. fortespinosus sp. n.

Coloration of forebody uniformly pale yellowish red. $\sigma^{\star}$ : ventral process of aedeagus long, in lateral view straight, and apically of different shape (Figs 42-43), in ventral view apically almost acute (Figs 44-45); internal sac of aedeagus with 6 less dark and slightly shorter spines (Fig. 47). Muğla: surroundings of Muğla (Map 1). S. sexspinosus sp. n.

9. $\sigma^{\pi}$ : aedeagus subapically not dentate and with relatively short ventral process (Figs A05a: 23-25). Southwest of Antalya province: Dumanlı Dağı (Map A05a: 2).

S. dumanlianus Assing

$\sigma^{\top}$ : aedeagus subapically dentate and with longer ventral process. Distribution different. . ...凶

10. Forebody darker and somewhat bicoloured: head dark brown, pronotum bright reddish, elytra brown. $\sigma^{*}$ : ventral process of aedeagus apically very slender and of distinctive shape (Figs 6-9); internal structures shaped as in Fig. 10. Izmir: Boz Dağlar (Map 1).

S. bozdagensis sp. $\mathrm{n}$.

Forbody uniformly reddish. $\sigma^{*}$ : ventral process of aedeagus apically less slender and of different shape; internal structures of aedeagus different (Figs A05b: 18-20). Southern Antakya (Map A05b: 3).

S. hatayanus AssiNG 
11. Abdomen darker, distinctly contrasting with the rufous forebody. Species from the western Taurus and western Anatolia (Antalya, Muğla). 12

Abdomen more weakly infuscate, less distinctly contrasting with rufous forebody. Species from the eastern Taurus (Mersin and eastwards). 15

12. $0^{*}$ : sternite VIII with densely pubescent median tubercle (Fig. A03: 21). Aedeagus shaped as in A03: 19-20, without sclerotized spines in internal sac. Southwestern Antalya: Ak Dağlar (Map A03: 2). S. brachati Assing $0^{\top}:$ sternite VIII with median process or fin-like tubercle. Aedeagus of different shape. Species with more western distributions. 13

13. $\sigma^{\top}$ : sternite VIII with conspicuous suberect median process (Figs A05a: 12-15). Aedeagus shaped as in Figs A05a: 16-19, with two semitransparent spines in internal sac. Muğla: Boncuk Dağ (Maps A05a: 1-2). S. aculeatus Assing $\sigma^{\star}$ : sternite VIII with fin-like tubercle (Figs 18, 56). Aedeagus and distribution different. ..凶

14. $0^{\top}$ : process of sternite VIII posteriorly rounded in lateral view and apically acute in ventral view (Figs 16-18); ventral process of aedeagus apically less slender in lateral view (Figs 1921). Izmir: surroundings of Karaburun (Map 1).

S. pinniger sp. n. $\sigma^{\star}$ : process of sternite VIII posteriorly obliquely truncate in lateral view and apically rounded in ventral view (Figs 53-56); ventral process of aedeagus apically more slender in lateral view (Fig. 57). Manisa: Karadağ (Map 1).

S. pinnatus sp. n.

15. $\sigma^{*}$ : apical part of ventral process of aedeagus shorter and stouter, ventral outline in lateral aspect not distinctly concave (Figs A05b: 3-5). Mersin (Map A05b: 3).

S. goektepensis Assing

$\sigma^{\top}$ : apical part of ventral process of aedeagus longer and more slender, ventral outline in lateral view concave. 16

16. $0^{\text {t }}$ : tubercle of abdominal sternite VIII with shorter pubescence (Fig. A01: 24); ventral process of aedeagus with very long and slender apical part and with more weakly concave basal part (lateral view); spines in internal sac smaller (Figs A01: 22-23). NW-Mersin (Map A01: 3).

S. tuberiventris Assing

$\sigma^{\star}$ : tubercle of abdominal sternite VIII with longer pubescence (Figs A01: 27, 30); ventral process of aedeagus with shorter apical part and with strongly concave basal part (lateral view); spines in internal sac larger. 17

17. $0^{-1}$ : aedeagus with apical part of ventral process longer and more slender, and with basal part of ventral process less broadly concave; spines in internal sac smaller (Figs A01: 25-26). W-Mersin (Map A01: 3). S. wunderlei Assing $\sigma^{\star}$ : aedeagus with apical part of ventral process shorter and stouter, and with basal part of ventral process more broadly concave; spines in internal sac larger (Figs A01: 28-29). EMersin (Map A01: 3).

S. balkarensis Assing

18. Abdominal tergite VII with palisade fringe at posterior margin. 19 Abdominal tergite VII without palisade fringe. 23

19. $0^{*}$ : sternite VIII with conspicuous cluster of modified stout black setae arranged in characteristic pattern (Fig. A95: 2). Aedeagus of characteristic morphology (Fig. A95: 1). In Turkey known only from the northwest (Istanbul). S. fallax (LOKAY) 
$0^{\text {* }}$ : sternite VIII without such clusters of modified setae. Aedeagus of completely different morphology. 20

20. Elytra in most specimens at least partly darker than pronotum. $\sigma^{\star}:$ sternite VII in posterior median area without distinctly diagonal pubescence; aedeagus more slender and with apically acute ventral process (best seen in lateral view).

Elytra in most specimens ferrugineous, of similar colour as the pronotum. $\sigma^{*}$ : sternite VII in posterior median area with diagonal pubescence; aedeagus stouter and with apically more or less truncate ventral process (lateral view).

21. Predominantly macropterous species; elytra at suture approximately as long as (submacropterous morph) or distinctly longer than pronotum (macropterous morph). $0^{\star}:$ aedeagus with ventral process apically more strongly bent in lateral view (Figs A01: 3-4). Known only from Antalya and Muğla provinces and from the Greek island Lesbos (Map A05b: 1, A05d: 111). S. anatolicus Assing

Usually brachypterous species; elytra at suture distinctly shorter (brachypterous morph) or approximately as long as pronotum (submacropterous morph). $0^{*}$ : aedeagus with ventral process apically less strongly bent in lateral view (Figs A01: 1-2). Widespread species, in Turkey recorded from the north and west (Map A05b: 1, A05d: 1).

S. melanocephalus (FABRICIUS)

22. Puncturation of pronotum denser. $\sigma^{*}$ : aedeagus smaller, ventral process in ventral view apically with lateral projections; rod-like structure in internal sac of aedeagus shaped as in Figs A01: 5-6. Widespread from central southern to eastern Anatolia and Iran (Map A05c: 1). S. phasianus (Bordoni) (macropterous morph)

Puncturation of pronotum sparser. $\sigma^{*}$ : aedeagus with ventral process in ventral view apically without or with very weak lateral projections; rod-like structure in internal sac shaped like a hoe (Figs A01: 17-19). Widespread from Antalya to eastern Anatolia (Map A05c: 1). ..

S. dolabrifer Assing

23. Head usually of the same colour as pronotum. Endemic species of Ak Dağlar (Muğla) and Nur Dağları (Antakya). 24

Head usually of darker colour than pronotum. More widespread species. 25

24. $0^{*}$ : ventral process of aedeagus in ventral view apically with lateral projections (Figs A03: 5-9). Muğla: Ak Dağlar (Map A05b: 2). S. akianus Assing $\sigma^{*}$ : ventral process of aedeagus in ventral view apically without lateral projections (Figs A01: 13-14). Antakya: Nur Dağları.

S. nurdaghensis Assing

25. Puncturation of pronotum denser. Elytra usually not infuscate. $\sigma^{*}$ : ventral process of aedeagus apically with larger (wing-like) lateral projections at a greater distance from apex (Figs A01: 5-6). Widespread from central southern to eastern Anatolia and Iran (Map A05c: 1)....

S. phasianus (BoRdoni) (brachypterous morph)

Puncturation of pronotum slightly sparser. Elytra usually infuscate in median and anterior area. $\sigma^{*}$ : ventral process of aedeagus apically with small projections nearer to apex (Figs A01: 8-9). Widespread from Antalya to eastern Anatolia (Map A05c: 1). 


\section{Acknowledgements}

My thanks are due to Paul Wunderle for the generous gift of the holotype of S. pinnatus, as well as to Benedikt Feldmann (Münster) for proof-reading the manuscript.

\section{References}

Assing, V. 1995: Über Sunius fallax (LoKAy, 1919) (Coleoptera, Staphylinidae). - Entomologische Nachrichten und Berichte 38 (1994): 267-269.

Assing, V. 2001: On the Turkish species of Sunius Curtis 1829 (Coleoptera: Staphylinidae, Paederinae). - Linzer biologische Beiträge 33: 195-210.

Assing, V. 2003: New species and records of Staphylinidae from Turkey (Insecta: Coleoptera: Staphylinidae). - Entomologische Blätter 98 (2002): 153-177.

Assing, V. 2005a: On the Turkish species of Sunius. IV. New micropterous species from southwestern Anatolia and additional records (Coleoptera: Staphylinidae, Paederinae). - Linzer biologische Beiträge 37: 415-423.

Assing, V. 2005b: On the Turkish species of Sunius. V. New species, additional records, a new synonymy, and an updated key to species (Coleoptera: Staphylinidae, Paederinae). - Beiträge zur Entomologie, Keltern 55: 109-121.

Assing, V. 2005c: On the Turkish species of Sunius. VI. New micropterous species from central southern Anatolia and additional records (Coleoptera: Staphylinidae, Paederinae). - Beiträge zur Entomologie, Keltern 55: 289-298.

Assing, V. 2005d: Two new species and new records of Staphylinidae from the Greek island Lesbos (Insecta: Coleoptera). - Linzer biologische Beiträge 37: 1035-1046.

\section{Author's address:}

Dr. Volker Assing

Gabelsbergerstr. 2

D - 30163 Hannover, Germany

e-mail: vassing.hann@t-online.de

\section{Subject editor:}

B. KLAUSNITZER

\section{Besprechungen}

Wyss, U.: Produktion von DVD Filmen am Institut für Phytopathologie, Universität Kiel.

Sequenzen über die Entwicklung einiger Insekten von der Eiablage bis zum erwachsenen Tier, über ihre Lebensweise sowie vom harten Überlebenskampf in einem oft unbekannten Mikrokosmos beobachten Prof. Wyss und sein Team unter dem Stereomikroskop und halten sie mit der Videokamera fest. Oft muss das Verhalten der Tiere geduldig über viele Stunden beobachtet werden, um wenige Sekunden davon einzufangen. Die Filme haben es allerdings bisweilen in sich, denn die Kieler Miniatur-Filmer haben inzwischen etliche Sequenzen aufgezeichnet, die nie zuvor in bewegten Bildern zu sehen waren. Deshalb zeigen inzwischen auch Fernsehsender Interesse an den Filmen. An internationalen Kongressen und Ausstellungen sind sie eine besondere Attraktion. Sie können auch Schülern, Studenten und an der Natur Interessierten empfohlen werden. Bisher sind 26 Titel verfügbar, 3 angekündigt und weitere in Vorbereitung: 